\title{
PELATIHAN INOVASI TEKNOLOGI SALE PISANG TANPA PENGGORENGAN PADA KELOMPOK PENGRAJIN PANDAWA DI DESA KARANGPAWITAN, KEC. PADAHERANG, KAB. PANGANDARAN
}

\author{
H. Aripin*1 ${ }^{1}$, Edvin Priatna ${ }^{1}$, Suyudi Suyudi ${ }^{2}$ \\ ${ }^{1}$ Jurusan Teknik Elektro, Fakultas Teknik, Universitas Siliwangi \\ 2Jurusan Agribisnis, Fakultas Pertanian, Universitas Siliwangi \\ *aripin@unsil.ac.id
}

\begin{abstract}
Banana fruit production in Karangpawitan Village, Kec. Padaherang was 11,573.9 tons in 2019 and that is almost $30 \%$ of the total production of bananas Kab. Pangandaran. Some of the bananas are processed into banana sale by the Pandawa group in the Padaherang district. The number of craftsmen who are members of the Pandawa group is 4 heads of families with 16 workers. In one week, the Pandawa group is able to process $480 \mathrm{~kg}$ of banana raw materials with an average output of $72 \mathrm{~kg}$ of dried banana sale. Currently, the banana sale drying process is done traditionally using the sun's heat for more than 6 hours. Due to cloudy or rainy weather, this situation makes the texture and color of the banana sale change and it is less dry and crunchy. Craftsmen also use conventional drying ovens, but it causes production losses of about $20-30 \%$ of defective banana sales in one week. After drying, the craftsmen then produce banana sale by frying and its characteristic is that the surface texture of the banana sale is coated with flour and the inside of the banana sale still contains the remnants of cooking oil. The problems faced by partners are (1) solar heat drying and conventional drying ovens result in a fairly large loss of banana sale production due to defective banana sales and (2) fried banana sale products on the market have started to be abandoned by some people because people understand the importance of unhealthy food products such as fried banana sales. The solution is to equip the banana sale drying oven with automatic temperature control to maintain a constant temperature in order to distribute the heat evenly in the oven. The purpose of this activity is to increase the knowledge and skills of the Mandala craftsman group in Karangpawitan Village, Padaherang District, Pangandaran Regency in making banana sales without frying using a drying oven with automatic temperature control. The number of participants is 25 members of the Pandawa craftsman group. The training was hold from 6 to 8 May 2021. This activity is carried out using training, practice, and mentoring methods. The training method is carried out by providing procedures for drying banana sale using an automatic drying oven. The practical method is carried out by practicing directly the use of an automatic drying oven. Technical assistance is carried out by placing student assistants to monitor partner activities from 15 May to 5 June 2021. The results of the questionnaire showed that the participants' interest in this activity was categorized as very good, especially for the aspect of community empowerment and community motivation to develop. The results also show that above $80 \%$ of participants are skilled in all aspects of operating an automatic banana sale drying oven, which indicates that participants can use and operate the drying oven independently without assistance.
\end{abstract}

Keywords: banana sale without frying, drying oven, automatic temperature control, unhealthy banana sale, defective banana sale

\footnotetext{
Abstrak

Produksi buah pisang Desa Karangpawitan, Kec. Padaherang adalah 11.573,9 ton tahun 2019 dan itu hampir $30 \%$ total produksi buah pisang Kab. Pangandaran. Sebagian pisang diolah menjadi sale pisang oleh kelompok pengrajin Pandawa di Kec. Padaherang. Jumlah pengrajin yang tergabung dalam kelompok Pandawa adalah 4 kepala keluarga dengan 16 orang pekerja. Dalam satu minggu, kelompok pengrajin Pandawa mampu mengolah bahan baku buah pisang $480 \mathrm{~kg}$. Dari total bahan baku yang diolah, hasil keluaran rata-rata sale pisang kering siap jual $72 \mathrm{~kg}$. Saat ini proses pengeringan sale pisang oleh pengrajin dilakukan secara tradisional menggunakan panas matahari selama lebih 6 jam. Karena cuaca mendung atau hujan, keadaan ini membuat tekstur dan warna sale pisang berubah serta kurang kering dan renyah. Pengrajin juga menggunakan oven pengering konvensional, namun itu menyebabkan kehilangan produksi sekitar 20 - 30\% dari sale pisang cacat dalam satu minggu. Setelah pengeringan, selanjutnya pengrajin memproduksi sale pisang dengan penggorengan dan itu mempunyai karakteristik tekstur permukaan sale pisang dilapisi tepung dan bagian dalam sale pisang masih mengadung sisa-sisa minyak goreng. Permasalahan yang dihadapi oleh mitra adalah (1) pengeringan panas matahari dan oven pengering konvensional menghasilkan tingkat kehilangan produksi sale pisang cukup besar karena sale pisang cacat dan (2) produk sale pisang goreng di pasaran sudah mulai ditinggalkan oleh sebagian masyarakat karena masyarakat sudah memahami pentingnya kesehatan dengan tidak memilih sale pisang yang berkolesterol. Solusi yang ditawarkan adalah melengkapi oven pengering sale pisang dengan kontrol suhu otomatis untuk
} 
menahan suhu konstan sehingga distribusi panas di dalam oven merata. Tujuan kegiatan ini adalah meningkatkan pengetahuan dan ketrampilan kelompok pengrajin Mandala di Desa Karangpawitan, Kec. Padaherang, Kab. Pangandaran dalam pembuatan sale pisang tanpa goreng menggunakan oven pengering dengan kontrol suhu otomatis. Jumlah peserta adalah 25 orang anggota kelompok pengrajin Pandawa. Pelaksanaan pelatihan adalah dari tanggal 6 sampai 8 Mei 2021. Kegiatan ini dilakukan dengan metode pelatihan, praktek, dan pendampingan. Metode pelatihan dilakukan dengan memberikan tatacara pengeringan sale pisang menggunakan oven pengering otomatis. Metode praktek dilakukan dengan mempraktekan langsung penggunaan oven pengering otomatis. Pendampingan secara teknis dilakukan dengan menempatkan pendamping mahasiswa untuk memantau kegiatan mitra dari tanggal 15 Mei sampai 5 Juni 2021. Hasil angket menunjukkan bahwa ketertarikan peserta dalam kegiatan ini terkatagori sangat baik terutama untuk aspek pemberdayaan masyarakat dan motivasi masyarakat untuk berkembang. Hasil juga menunjukkan bahwa di atas $80 \%$ peserta terampil dalam semua aspek kegiatan pengoperasian oven pengering sale pisang otomatis, yang mengindikasikan bahwa peserta dapat menggunakan dan mengoperasikan oven pengering secara mandiri tanpa bantuan pendampingan.

Kata kunci: sale pisang tanpa pengorengan, oven pengering, kontrol suhu otomatis, sale pisang tidak sehat, sale pisang cacat

\begin{tabular}{l|l|l} 
Submitted: $2021-06-04$ & Revised: $2021-07-13$ & Accepted: 2021-07-31
\end{tabular}

\section{Pendahuluan}

Lokasi kegiatan Pengabdian Masyarakat adalah di Desa Karangpawitan, Kec. Padaherang, Kab. Pangandaran yang berjarak $120 \mathrm{~km}$ dari Universitas Siliwangi Tasikmalaya. Mayoritas penduduknya adalah bertani dengan menggarap lahan pesawahan, perkebunan kelapa dan pisang. Potensi buah pisang Kec. Padaherang hampir 30\% total produksi buah pisang Kab. Pangandaran yang mencapai 11.573,9 ton tahun 2019 (Badan Pusat Statistik, 2019). Pohon pisang tumbuh dalam bentuk hamparan perkebunan yang dipelihara masyarakat dan hampir semua kepala keluarga memiliki tanaman pisang. Hasil panen pisang dijual ke kelompok usaha pengolahan buah pisang. Kelompok pengrajin sale pisang Pandawa adalah salah satu kelompok usaha yang mengembangkan pengolahan buah pisang menjadi sale pisang di Kec. Padaherang. Jumlah pengrajin yang tergabung dengan kelompok Pandawa adalah 4 kepala keluarga dengan 16 orang pekerja. Dalam satu minggu, kelompok pengrajin Pandawa mampu mengolah bahan baku buah pisang $480 \mathrm{~kg}$. Dari total bahan baku yang diolah, hasil keluaran rata-rata sale pisang siap jual 72 $\mathrm{kg}$. Permintaan pasar mencapai $200 \mathrm{~kg} / \mathrm{minggu}$ atau hampir 3 kali lipatnya. Wilayah pemasaran adalah sentra oleh-oleh di Kab. Garut, Kota Bandung dan Prov. DKI Jakarta dan daerah lokal pada tempat-tempat wisata di Pantai Pangandaran. Harga sale pisang untuk kedua jenis sale adalah Rp.22.000,-/kg.

Proses pembuatan sale pisang pada kelompok pengrajin Pandawa terdiri dari proses pengupasan dan pemotongan buah pisang, pengeringan, penggorengan dan pengemasan sale pisang. Saat ini proses pengeringan sale pisang oleh pengrajin masih dilakukan secara tradisional dengan mengeringkan sale pisang di ruang terbuka menggunakan panas matahari. Untuk memperoleh sale pisang kering siap jual, itu memerlukan proses pengeringan dengan panas matahari rata-rata selama $5-6$ jam. Keadaan ini dicapai jika panas matahari yang diterima konstan dan cuaca cerah. Sale pisang yang dikeringkan lebih dari 6 jam akan membuat tekstur dan warna sale pisang berubah, sedangkan sale pisang yang kurang kering akan kurang renyah bila dimakan. Kondisi sale pisang seperti itu tidak akan laku untuk dijual. Disamping pengeringan dengan panas matahari, kelompok pengrajin juga menggunakan oven pengering untuk mengeringkan sale pisang. Kapasitas pengisian sale pisang dalam oven pengering maksimum 60 kg. Proses pengeringan dengan oven berbahan bakar kayu bakar dilakukan selama 3 hari dan 2 malam untuk mendapatkan sale pisang siap jual. Panas yang ditimbulkan oleh bahan bakar pada oven pengering tidak merata, sehingga membuat sale pisang berubah warna dan terbakar. Dari 60 $\mathrm{kg}$ bahan baku sale pisang yang dikeringkan dalam oven pengering, itu menghasilkan sale pisang kering kualitas jual sebanyak $9 \mathrm{~kg}$ dan sale pisang cacat karena berubah warna dan terbakar sebanyak $3 \mathrm{~kg}$. Berdasarkan jumlah oven pengering yang digunakan oleh pengrajin sale pisang 
saat ini, dapat diperkirakan bahwa sekitar $24 \mathrm{~kg}$ sale pisang cacat dihasilkan dalam satu minggu. Kelompok pengrajin mengalami kerugian sekitar $24 \mathrm{~kg}$ sale pisang dalam satu minggu bila menggunakan oven pengering karena kondisi pisang yang cacat ini tidak bisa dijual atau dipasarkan.

Pada proses penggorengan, sale pisang dengan campuran tepung dan gula diolah menggunakan minyak goreng. Produk sale pisang goreng ini mengandung asam lemak trans, senyawa polimer dan sumber kolesterol (Ulfa dkk, 2017). Dalam satu pisang goreng mengandung rata-rata 3,58 g lemak, termasuk lebih dari $50 \mathrm{mg}$ kolesterol. Kondisi seperti ini akan menambah tumpukan lemak jenuh dalam tubuh.

Atas dasar analisis situasi yang diuraikan di atas, maka ditemukan permasalahan mitra adalah:

a. Tingkat keluaran produk sale pisang cacat cukup besar mencapai $20-30 \%$ dari total produk pisang sale kering yang dihasilkan oleh pengeringan panas matahari dan oven pengering konvensional. Produk sale pisang cacat disebabkan kotoran, perubahan tekstur, perubahan warna dan terbakar. Itu berakibat pada kerugian mitra kelompok pengrajin dalam proses produksi karena produk sale pisang cacat tidak laku dijual.

b. Mitra memproduksi sale pisang dengan penggorengan padahal produk sale pisang goreng di pasaran sudah mulai ditinggalkan oleh sebagian masyarakat karena masyarakat sudah mengerti pentingnya kesehatan dengan tidak memilih sale pisang yang berkolesterol.

Tujuan kegiatan ini adalah meningkatkan pengetahuan dan ketrampilan kelompok pengrajin Mandala di Desa Karangpawitan, Kec. Padaherang, Kab. Pangandaran dalam pembuatan sale pisang tanpa goreng menggunakan oven pengering dengan kontrol suhu otomatis. Oven pengering ini berfungsi ganda yaitu yang pertama untuk mengurangi produk sale pisang cacat selama pengeringan dan yang kedua untuk mempertahankan suhu konstan dalam jangka waktu tertentu untuk memproduksi sale pisang kering berkualitas.

\section{Metode}

1. Kegiatan Persiapan

Kegiatan persiapan terdiri dari:

a. Observasi awal dilakukan dalam menganalisis masalah yang dihadapi oleh mitra pada pembuatan sale pisang dengan wawancara dan observasi kepada pimpinan dan anggota kelompok Pandawa di Desa Karangpawitan, Kec. Padaherang, Kab. Pangandaran.

b. Persiapan program meliputi penyusunan jadwal kegiatan yang disepakati bersama dan susunan acara pelatihan, dan menyiapkan perlengkapan penyelenggaraan pelatihan.

c. Rapat pemantapan materi dan pengecekan kebutuhan kegiatan bersama tim pengabdian.

\section{Pelaksanaan Kegiatan}

Pelaksanaaan kegiatan pelatihan inovasi teknologi sale pisang tanpa goreng diberikan kepada 25 orang dari Kelompok Pandawa di Desa Karangpawitan, Kec. Padaherang, Kab. Pangandaran. Pelaksanaan kegiatan ini menggunakan metode pelatihan dan metode praktek (learning by doing) dengan memberikan praktek pengeringan sale pisang menggunakan oven pengering otomatis. Secara garis besar tahapan pelaksanaan kegiatan adalah sebagai berikut:

\subsection{Pelatihan Teori}

Kegiatan pelatihan teori terdiri dari:

a. Program pengabdian kepada masyarakat dalam bentuk pelatihan pembuatan sale pisang dan pengeringannya.

b. Potensi buah pisang dan lainnya di Desa Karangpawitan, Kec. Padaherang, Kab. Pangandaran.

c. Mengatasi kekurangan bahan baku untuk sale pisang.

d. Strategi bisnis dan pemasaran sale pisang goreng dan tanpa goreng dan kendalanya.

e. Metode pembuatan sale pisang siam dan ambon dan karakteristiknya. 
f. Metode pengeringan sale pisang konvensional dan modern dengan pengering bimassa.

\subsection{Pelatihan Praktek}

Kegiatan pelatihan praktek pengeringan sale pisang terdiri dari:

a. Sale pisang disiapkan dari pisang ambon dan kemudian dikupas untuk memisahkan bagian buah pisang dan kulitnya.

b. Buah pisang diletakkan dan disusun di atas tampah yang terbuat dari ram kawat.

c. Oven pengering dihidupkan dengan pembakaran bahan bakar dan pintunya dibuka selama 20 menit untuk mengeluarkan gas-gas pengotor yang timbul pada pembakaran awal.

d. Tampah yang berisi pisang dimasukkan ke dalam rak-rak oven pengering kemudian pintu oven pengering ditutup rapat.

e. Pada bagian kontrol oven pengering, suhu oven diatur dalam rentang dari $75^{\circ} \mathrm{C}$ sampai $80^{\circ} \mathrm{C}$ selama 8 jam.

f. Selalu memonitor tampilan layar penunjuk suhu oven.

g. Setelah selesai pengeringan, sale pisang dikeluarkan dari dalam oven pengering, kemudian dipastikan bahwa kadar air sale pisang kurang dari $20 \%$.

\section{Pendampingan}

Kegiatan pendampingan kelompok mitra dilakukan dari tanggal 15 Mei sampai 5 Juni 2021 dengan penempatkan pendamping secara periodik dua kali seminggu untuk memantau kegiatan mitra dalam menindaklanjuti pengeringan sale pisang dengan oven pengering dan memantau kedisiplinan mitra dalam menggunakan oven pengering.

Tabel 1. Angket pelaksanaan kegiatan pengabdian kepada masyarakat

\begin{tabular}{cl}
\hline No & \multicolumn{1}{c}{ Item pertanyaan } \\
\hline 1 & Kesesuaian kegiatan pengabdian dengan kebutuhan masyarakat \\
2 & Kerjasama pengabdi dengan masyarakat peserta pelatihan \\
3 & Memunculkan aspek pemberdayaan masyarakat \\
4 & Meningkatkan motivasi masyarakat untuk berkembang \\
5 & Sikap/perilaku pengabdi di lokasi pengabdian \\
6 & Komunikasi/ koordinasi Tim Pengabdi dengan masyarakat \\
7 & Kesesuaian waktu pelaksanaan dengan kegiatan masyarakat \\
8 & Kesesuaian keahlian pengabdi dengan kegiatan pengabdian \\
9 & Kemampuan mendorong kemandirian/ swadaya masyarakat \\
10 & Hasil pengabdian dapat dimanfaatkan masyarakat \\
\hline
\end{tabular}

\section{Monitoring dan Evaluasi}

Pemantauan dan evaluasi dilakukan sampai kelompok mitra bisa mandiri dalam menghasilkan produk sale pisang berkualitas dan menjalankan usahanya secara berkelanjutan sehingga secara keseluruhan tujuan, target dan luaran kegiatan ini dapat tercapai dengan baik. Tabel 1 dan 2 berturut-turut menunjukkan angket pelaksanaan kegiatan pengabdian kepada masyarakat dan intrumen pemantauan dan evaluasi pengabdian kepada masyarakat. Angket pelaksanaan kegiatan pengabdian kepada masyarakat diberikan ke peserta pelatihan setelah pelatihan dilaksanakan dan pemantauan dilakukan setelah pendampingan dilakukan.

Tabel 2. Intrumen monev setelah kegiatan pengabdian kepada masyarakat

\begin{tabular}{cl}
\hline No & \multicolumn{1}{c}{ Item pertanyaan } \\
\hline 1 & Peserta trampil mengoperasikan oven pengering \\
2 & Peserta trampil pengontrolan suhu oven \\
3 & Peserta trampil membuat ketepatan suhu pengeringan \\
4 & Peserta trampil membuat sale pisang tanpa cacat
\end{tabular}


$5 \quad$ Peserta trampil membuat pengeringan merata

6 Peserta trampil produksi $120 \mathrm{~kg}$ sale pisang dalam satu minggu

7 Peserta trampil menjaga keselamatan kerja selama operasi pengeringan

8 Peserta trampil menghasilkan sale pisang kering dengan kadar air kurang dari $15 \%$

\section{Hasil dan Pembahasan}

Gambar 1 menunjukkan oven pengering otomatis untuk pengeringan sale pisang. Oven ini dilhami oleh oven pengering kelom geulis (Priatna dkk, 2016). Oven pengering dengan kontrol suhu otomatis untuk menahan suhu konstan untuk sale pisang di dalam oven pengering. Panas lingkungan di dalam oven pengering berasal dari panas api yang merambat melalui konduktor yang digunakan sebagai dinding ruang oven pemanas. Perpindahan panas terjadi dari suhu lingkungan yang lebih tinggi ke buah pisang yang suhunya rendah. Perpindahan panas akan terus berlangsung sampai ada kesetimbangan panas yang terjadi diantara dua media tersebut. Dengan adanya konduktor sebagai dinding pada keseluruhan ruang oven pemanas, maka pemanasan sale pisang terdistribusi merata di dalam oven pengering (Shabrina dan Susanto, 2017; Kastiawan dan Salamun, 2019; Pratama dkk, 2019), sehingga tidak berakibat pada perubahan tekstur, perubahan warna dan terbakar. Rambatan panas yang merata ke segala arah dalam buah pisang menyebabkan keluarnya uap air dari buah pisang dan berakibat pada pengeringan buah pisang. Pengeringan buah pisang ini harus diimbangi oleh kecepatan gerakan air menuju permukaan buah pisang.

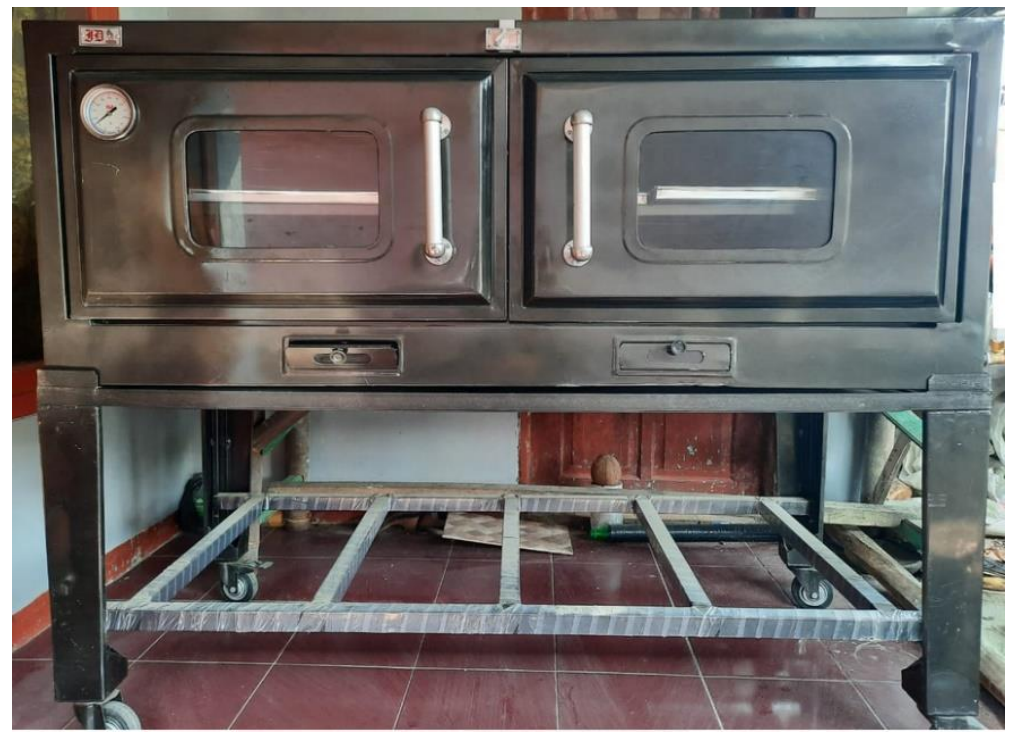

Gambar 1. Oven pengering otomatis yang digunakan dalam kegiatan Pengabdian Kepada Masyarakat. 

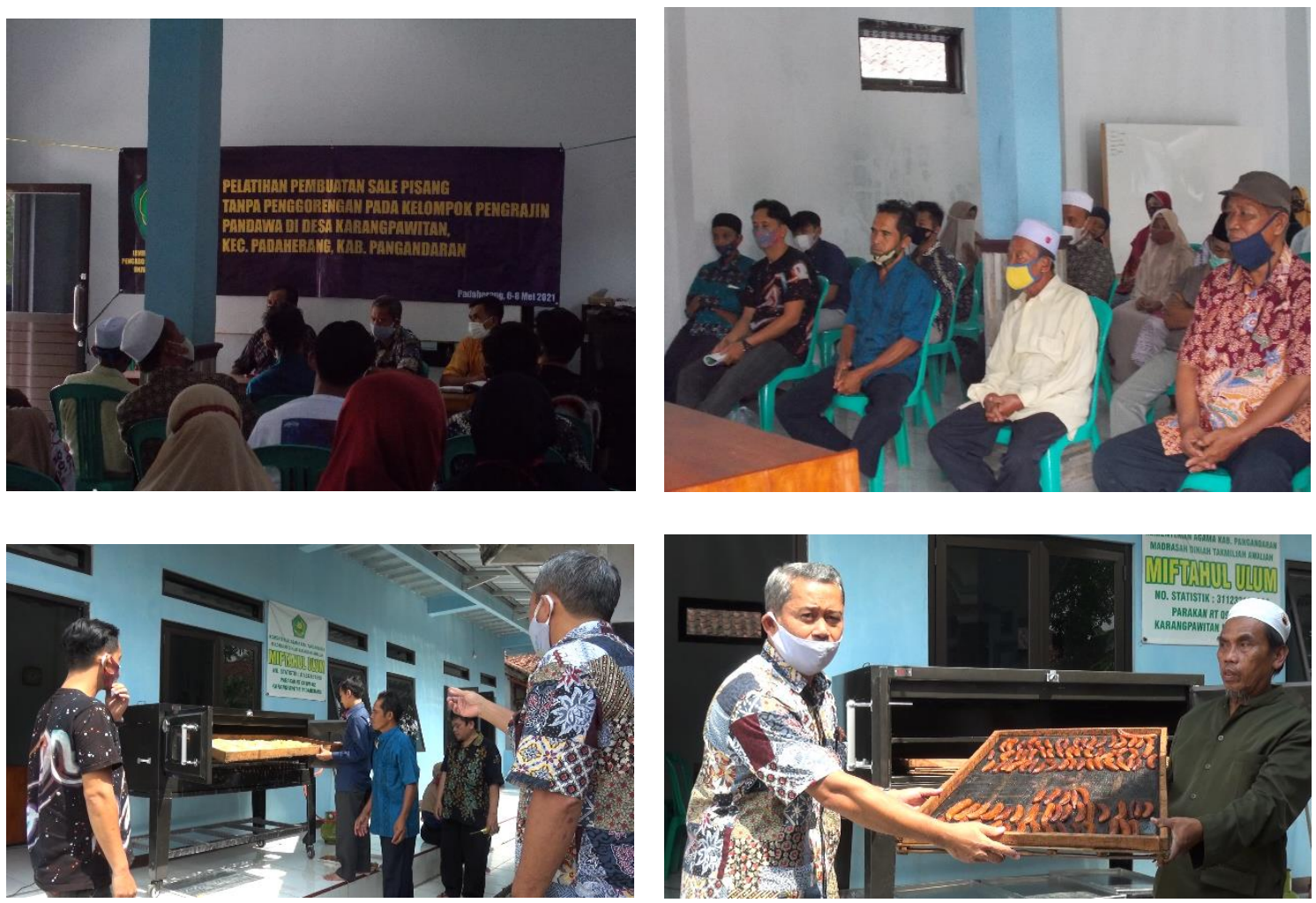

Gambar 2. Pelaksanaan kegiatan pelatihan pembuatan sale pisang tanpa penggorengan pada kelompok pengrajin Pandawa di Desa Karangpawitan, Kec. Padaherang, Kab. Pangandaran.

Gambar 2 menunjukkan pelaksanaan kegiatan pelatihan pembuatan sale pisang tanpa penggorengan pada kelompok pengrajin Pandawa di Desa Karangpawitan, Kec. Padaherang, Kab. Pangandaran. Kegiatan pengabdian ini dilakukan melalui pelatihan dan praktek pembuatan sale pisang tanpa penggorengan menggunakan oven pengering. Pelatihan dan praktek dilaksanakan pada hari Kamis, 6 Mei 2021 sampai hari Sabtu, 8 Mei 2021. Para peserta yang hadir dalam kegiatan tersebut sebanyak 25 orang dari kelompok pengrajin Pandawa di Desa Karangpawitan, Kec. Padaherang, Kab. Pangandaran.

Tabel 3. Data ketercapaian pelaksanaan kegiatan pelatihan pembuatan sale pisang tanpa penggorengan menggunaka oven pengering.

\begin{tabular}{lcc}
\hline \multicolumn{1}{c}{ Item pertanyaan } & Skor & Katagori \\
\hline Kesesuaian kegiatan pengabdian dengan kebutuhan masyarakat & 3,12 & Baik \\
Kerjasama pengabdi dengan masyarakat peserta pelatihan & 3,04 & Baik \\
Memunculkan aspek pemberdayaan masyarakat & 3,62 & Sangat baik \\
Meningkatkan motivasi masyarakat untuk berkembang & 3,56 & Sangat baik \\
Sikap/perilaku pengabdi di lokasi pengabdian & 3,08 & Baik \\
Komunikasi/ koordinasi Tim Pengabdi dengan masyarakat & 3,12 & Baik \\
Kesesuaian waktu pelaksanaan dengan kegiatan masyarakat & 3,04 & Baik \\
Kesesuaian keahlian pengabdi dengan kegiatan pengabdian & 3,12 & Baik \\
Kemampuan mendorong kemandirian/swadaya masyarakat & 3,61 & Sangat baik \\
Hasil pengabdian dapat dimanfaatkan masyarakat & 3,04 & Baik \\
\hline
\end{tabular}

Tabel 4. Hasil pengolahan instrumen monev terkait keterampilan peserta dalam pelatihan pembuatan sale pisang tanpa penggorengan menggunaka oven pengering.

\begin{tabular}{ccc}
\hline Item pertanyaan & Prosentase & Katagori \\
\hline Mengoperasikan oven pengering & 82,04 & Baik
\end{tabular}


Pengontrolan suhu oven

Pengaturan ketepatan suhu pengeringan

Membuat sale pisang tanpa cacat

Membuat pengeringan merata

Memproduksi $120 \mathrm{~kg}$ sale pisang dalam satu minggu

Menjaga keselamatan kerja selama operasi

pengeringan

Menghasilkan sale pisang kering dengan kadar air kurang dari $15 \%$
81,34

76,15

83,12

80,24

80,75

82,54

75,03
Baik

Kurang

Baik

Baik

Baik

Baik

Kurang

Tabel 3 menunjukkan data pendapat peserta yang mengikuti pelatihan pembuatan sale pisang menggunakan oven pengering otomatis. Skor rata-rata jawaban angket dari 25 orang peserta menunjukkan bahwa semua item pertanyaan angket dijawab dengan katagori baik dan sangat baik. Ada tiga item pertanyaan yang dijawab dengan katagori sangat baik. Untuk item pertanyaan tentang motivasi masyarakat untuk berkembang, masyarakat memandang bahwa produksi sale pisang tanpa penggorengan ini sebagai pengembangan usaha bisnis sale pisang yang ada saat ini. Setelah ada oven pengeringan otomatis, produksi sale pisang akan bertambah karena pada saat kondisi hujan dan mendung, pengeringan sale pisang akan tetap berlangsung. Itu berbeda ketika sale pisang dikeringkan menggunakan sinar matahari terbuka, selain terbatas oleh cuaca ketika mendung atau hujan, pengeringan berhenti, sehingga produksi sale pisang terhambat sedangkan permintaan pasar mendesak. Disamping itu, pengeringan terbuka dengan sinar matahari juga menyebabkan kualitas sale pisang berkurang atau kurang higienis (bersih dan bebas penyakit). Selanjutnya skor tinggi untuk aspek pemberdayaan, itu juga dimotivasi oleh efek samping penggunaan oven pengering konvensional berbahan bakar kayu bakar digunakan oleh kelompok pengrajin. Api yang ditimbulkan oleh pembakaran kayu bakar terpusat sehingga panas yang ditimbulkan dalam oven tidak merata, sehingga pisang yang terkena oleh intensitas api tinggi, tektur pisang menjadi rusak terbakar/gosong sedangkan pisang yang terkena oleh intensitas api rendah, pisangnya tidak kering dan lembek. Dengan adanya pelatihan ini, masyarakat menerima pengetahuan untuk mengembangkan produksi sale pisang dengan merubah tingkat kadar air sale pisang dari 30\% menjadi di bawah 15\% (Marwati dkk, 2017) menggunakan oven pengering otomatis, sehingga dengan ini dapat meningkatkan produksi sale pisang. Selanjutnya, peserta pelatihan juga tertarik terhadap pertanyaan tentang munculnya aspek pemberdayaan masyarakat. Meskipun saat ini sebagian masyarakat sudah terjun mengelola usaha produksi sale pisang, tetapi masyarakat masih penasaran dengan produksi sale pisang tanpa penggorengan. Pandangan masyarakat menunjukkan bahwa sale pisang yang dibuatnya berbeda dengan sale pisang tanpa penggorengan, sehingga jika sale pisang yang dibuatnya bisa dikembangkan maka jangkauan pemasaran untuk sale pisang ini lebih luas. Pasar sale pisang yang semula adalah masyarakat kecil, setelah dikembangkan dapat menjangkau pasar dari masyarakat kecil sampai tingkat menengah, karena sale pisang ini tidak mengandung lemak/kolesterol, dan konsumen yang sudah paham tentang kesehatan menjadi pasar sale pisang tanpa penggorengan. Pada pertanyaan tentang kemampuan mendorong kemandirian/swadaya masyarakat, itu juga berkatagori sangat baik. Peserta tidak ragu dengan pelatihan ini dan menganggap bahwa pelatihan ini bermanfaat untuk mendorong usaha sale pisang menjadi berkembang. Itu didasarkan pada kenyataan bahwa peserta sudah mempunyai kemampuan dan pengalaman dalam memproduksi sale pisang dengan teknologi konvensional. Ketika ada inovasi dalam pembuatan sale pisang, peserta merasa tertarik dan termotivasi untuk mengembangkan sale pisang dalam rangka untuk memperluas usaha produksi sale pisang tanpa penggorengan.

Tabel 4 menunjukkan hasil pengolahan instrumen monev terkait keterampilan peserta dalam pembuatan sale pisang menggunakan oven pengering otomatis. Itu dapat dilihat bahwa jawaban untuk semua pernyataan berkatagori baik prosentasenya di atas $80 \%$. Peserta masih kesulitan 
dalam mengatur ketepatan suhu pengeringan pada rentang $75^{\circ} \mathrm{C}$ sampai $80^{\circ} \mathrm{C}$, karena sumber pemanas dari ruang pembakaran menimbulkan api yang intensitasnya kadang naik dan turun. Kesulitan lain dari peserta selama pelatihan adalah menghasilkan sale pisang dengan kadar air kurang dari $15 \%$. Setelah dua kali melakukan percobaan untuk melakukan pengeringan sale pisang, selalu menghasilkan sale pisang dengan kadar air antara 15\% dan 23\%, hal ini disebabkan oleh kurang optimumnya waktu pengeringan. Jumlah peserta untuk keterampilan berada di atas $80 \%$ dari peserta keseluruhan, yang berarti ketercapain kegiatan pelatihan pembuatan sale pisang tanpa penggorengan dengan oven pengering otomatis berkatagori baik. Hasil yang dicapai menunjukkan bahwa peserta pelatihan sudah mampu mempraktekan sendiri wawasan dan keterampilan yang diperoleh selama pelatihan.

\section{Kesimpulan}

Berdasarkan hasil kegiatan dan pembahasan, maka kesimpulan adalah sebagai berikut:

a. Pelatihan pembuatan sale pisang tanpa penggorengan menggunakan oven pengering suhu otomatis telah berhasil dilaksanakan dengan penyerapan materi teori dan praktek oleh peserta dikatagorikan terampil sangat baik. Penahanan suhu konstan dalam oven pengering untuk menjaga tekstrur dan warna sale pisang selama pengeringan menjadi pengetahuan baru bagi peserta. Di samping itu, peluang usaha pemberdayaan masyarakat untuk mengembangkan usaha pembuatan sale pisang tanpa penggorengan dapat menjangkau pasar yang lebih luas.

b. Prosentase keterampilan peserta pada semua aspek kegiatan pelatihan pembuatan sale pisang tanpa penggorengan adalah berkatagori di atas $80 \%$. Hasil menunjukkan bahwa peserta mampu mempraktekan sendiri wawasan dan keterampilan yang diperoleh selama pelatihan, sehingga peserta dapat membuat pisang sale tanpa penggorengan menggunakan oven pengering secara mandiri tanpa bantuan pendampingan.

\section{Ucapan Terima Kasih}

Penulis mengucapkan terima kasih kepada Direktorat Riset dan Pengabdian Masyarakat (DRPM) yang telah mendanai kegiatan Pengabdian Kepada Masyarakat melalui Skema Program Kemitraan Masyarakat (PKM) Tahun 2021. Di samping itu, penulis juga ingin mengucapkan banyak terima kasih kepada Bapak Saeful Milah yang menfasilitasi kegiatan dengan mitra.

\section{Daftar Pustaka}

Badan Pusat Statistik (2019), Jawa Barat.

Kastiawan, I. M., T, R. A. and Salamun, K. (2019) 'Rancangan Bangun Oven untuk Produksi Sale Pisang Dengan Sumber Panas dari Tungku Tradisional', Jurnal Teknik Mesin - Mekanika, 5(1), pp. 25-30.

Marwati dkk. (2017) 'Pengaruh Suhu Dan Lama Pengeringan Terhadap Sifat Kimia Dan Organoleptik Sale Pisang Kapas (Musa Comiculata)', Jurnal Kimia Mulawarman, 15(1), pp. 22-26. doi: $10.30872 / j k m . v 15 i 1.494$.

Pratama, P., Faisal, M. and Muhtadin (2019) 'Aplikasi Oven Pengering Biji Pala Dengan Memanfaatkan Udara Panas Tungku Pembakaran', SEMDI UNAYA-2019, pp. 774-781.

Priatna, E., Maftuh, A. and Sujudi (2016) 'Pengembangan Sistem Pengering Kelom Geulis Berbasis Mikrokontroler Dengan Dua Sisi Berpemanas Pipa', 9(2), pp. 172-176.

Shabrina, Z. U. and Susanto, W. H. (2017) 'Pengaruh Suhu dan Lama Pengeringan dengan Metode Cabinet Dryer Terhadap Karakteristik Manisan Kering Apel Varietas Anna (Malus Domestica Borkh)', Jurnal Pangan dan Agroindustri, 5(3), pp. 60-71.

Ulfa, V. R., Subagjo, H. W. and Nuryanto (2017) 'Gambaran Konsumsi Asam Lemak Trans di Pedesaan', Journal of Nutrition College, 6(2), pp. 210-218. 